\title{
Speaking up without Freaking out
}

\author{
Nurul Aldillah \\ Universiti Sains Malaysia, Malaysia \\ nurul@,usm.my
}

\begin{abstract}
It has been reported that language learners use various strategies in learning a second or foreign language and a lot of researches have been done in this area. However, few studies have explored the impact of using scaffolding impromptu speaking activities in ESL classroom on alleviating speaking anxiety. Thus, the current study is an attempt to investigate whether scaffolding impromptu speech activities could help the students to perform better during oral presentation and reduce their speaking anxiety. At the beginning of the study, the students were asked to answer online questionnaire on speaking anxiety experience while holding an oral presentation tasks or assessment. 38 undergraduate students did the prepared impromptu speaking activities such as they have to do self-video recorded, impromptu speech in group and online discussion. This intervention was carried out for six weeks. After that, another online questionnaire on the effectiveness of scaffolding impromptu speaking activities was distributed. However, I only received 25 responses from the participants. Besides that, participants' views about the impromptu speaking activities were also examined through focus group interview. The results of the study indicated that by scaffolding impromptu speaking activities in ESL classroom, the students were able to reduce their speaking anxiety and enhance their oral presentation skill.
\end{abstract}

Keywords: presentation skill, scaffolding, speaking anxiety

\section{Introduction}

In the educational world, Daly says speaking is seen as a necessary, positive personal characteristic (as cited in Suleimenova, 2013). However, foreign language learners often express feelings of stress, nervousness or anxiety while learning to speak the target language and claim to have 'mental block' against learning (Suleimenova, 2013). Campbell and Ortiz (1991) found language anxiety among university students to be 'alarming' and estimated that up to one half of all language students experience debilitating levels of speaking anxiety.

Language anxiety has been considered to be an important affective variable in foreign language learning process because anxiety can obstruct the learning process (Ellis, 1996; Hilleson, 1996; Horwitz, Horwitz \& Cope, 1986; Kaya, 1995; Koba, Ogava \& Wilkinson, 2000; MacIntyre \& Gardner, 1991; MacIntyre, Gardner \& Moorcroft, 1987; Price, 1991; Tsui, 1996; Young, 1991). Research has provided abundant evidence for its existence and its impact on the learning development. Anxiety has been found to be associated negatively with language performance and language proficiency. Tallon (2009) indicates that many factors determine the outcome of the learning process, including individual differences such as cognitive abilities, personality characteristics, learning styles, meta-cognitive differences, social contexts, and affective aspects. 
He points out that one of the most important affective variables in learning a foreign language is foreign language anxiety.

Therefore, this study looks deeply into the problems faced by the tertiary level second language (L2) learners in speaking. Based on the observations done in the classroom, most learners were found to have anxieties in delivering speech, presenting, as well as participating in a simple group discussion. At higher education level, this problem is quite a concern for these undergraduates have begun to learn English since elementary school. This chapter is organized as follows: the first section is the background of the study, followed by the research objective of the research. The purpose of this study is to investigate whether scaffolding impromptu speech activities could help the students to improve their speaking skills and reduce speaking anxiety.

\section{Literature Review}

Speaking anxiety is characterized by fear and anxiety in communicating with people, such as difficulty in speaking in public, listening or learning a spoken utterance are all manifestations of communication apprehension. This type of anxiety in learning a second language is derived from the learners' personal knowledge that they will have difficulty understanding others and making themselves understood. Learners suffering from communication apprehension choose to keep silent in their English classes. Daly (1991) states that one of the most studied topics in the field of speech communication is the tendency on the part of some people to avoid, and even, fear, which is communicating orally. Horwitz et al. (1986) define communication apprehension (CA) as "a type of shyness characterized by fear or anxiety about communicating with people".

The scaffolding includes all the things that teachers do already when they predict the kinds of difficulty that the class or individual students in it will have with a given task. ESL students greatly benefit from the type of scaffolding that makes extensive use of visual or visual scaffolding. When students can see an image of what the teacher is describing or see the key words that the teacher is explaining, this not only serves to make the input considerably more comprehensible, but serves to remove the affective filter which results from the fear or boredom that comes of understanding very little in class.

\section{Methods}

\section{Research design}

This action research is a mixed-research study followed the one group pre-test and posttest design. In this research design, the quantitative data included responses in the questionnaire on speaking anxiety and the effectiveness of scaffolding impromptu speaking activities. Meanwhile, the qualitative data included focus group interview to five volunteered students from the participants.

\section{Research site and participants}

The study was conducted in the Universiti Sains Malaysia, Kubang Kerian Campus in Kubang Kerian, Kelantan. It involved 38 students who were from the School of Medical and Sciences. 18 of the students were taking Scientific and Medical English course and 20 of the students were taking Academic English course as a compulsory subject upon their Degree completion. The sample consisted of three main ethnics in Malaysia which were Malay, Chinese and Indian yet the group was largely dominated by the Malays. They also had a catchment area where students came from mixed background, ranging from poor to wealthy families. Furthermore, the English course was a compulsory pass course; therefore, the students had to do well in order to be awarded distinction result upon their degree completion. 38 selected students from two English classes responded to the 10 items in the online questionnaire 
regarding their speaking anxiety. Scaffolding impromptu speaking activities were carried out for 6 weeks. Then, the students were given another online questionnaire on the effectiveness of scaffolding impromptu speaking activities. Finally, focus group interview was conducted to five volunteered students from participants.

\section{Data collection and analysis}

Two sets of information were needed for writing the final report of this research. they were required to answer the research question. I had to make sure that all participants answer the first and second questionnaire forms. Questionnaire was designed for collecting the students' response during pre and post-test concerning their opinion upon their speaking anxiety as well as the factors that contribute towards the issue. After that, a six weeks' course was designed for the students in combating their speaking anxiety. Basically the original plan was to have five weeks course yet I felt that having five meetings were important for the students and it would be great to see them performing using the target language and that was why chosen a six week timeframe was chosen whereby the sixth meeting would be the assessment week. There were a few components which had been highlighted in the program where throughout the program the main objective was to uplift their anxiety so that they were able to use the language fluently without any worries through speaking. The course was designed in line with the requirement of the course assessment which needed to be sat by the students.

During these six weeks of English lessons, the individual and group work task had been done so that the students could get themselves familiarized with the assessment later. As for the individual task, the students were asked to do their own video recording so that they would feel comfortable speaking to themselves first in front of their camera. They could talk on any topics that they wanted and feeling comfortable with. This was a way to help them in reducing their speaking anxiety. All the recordings were uploaded on the Edmodo which supported their virtual learning environment. Then the students also did an impromptu speech based on the topics which they were assigned every week.

Next would be the group work task. Personally, I believe that the students are able to deliver in front of their friends without any worries as their friends would be their first audience for the assessment. As a result, a module had been designed by giving them a challenging group work in order to improve their proficiency throughout the week whereby they did a mini project and it had to be consecutively carried out as this would prepare them for the assessment week in the sixth meeting. The second questionnaire consisted of ten questions regarding the implementation of scaffolding impromptu speaking activities to enhance speaking skill and reduce speaking anxiety. This questionnaire was distributed after the participants had gone through all the impromptu speaking activities. However, only 26 of the participants responded to the second questionnaire. However, one of the limitations in this study was not all the respondents answered both questionnaires. This was mainly because I could not monitor all the participants in answering the questionnaires as both questionnaires were online questionnaires. Frequencies and percentages were used to determine the extent of scaffolding impromptu speaking activities can enhance students' speaking skill and reduce their speaking anxiety. Semistructured interview questions were applied to examine the students' feelings about the use of scaffolding impromptu speaking activities and their level of anxiety.

\section{Discussion}

This questionnaire 1 was designed to collect the data on the participants' current proficiency level pertinent to speaking skill and their anxiety level before departing into a more serious business of dissecting the information hence helping them to counter their problem. From the data analysis for the question 1, it showed that $60.53 \%$ or 23 of the participants agreed 
that they felt tensed and nervous when preparing for giving the speech in English. Only one of the participants responded strongly disagree for item 1 . This showed that their level of speaking anxiety was high when it came to give speech in English. For item 2, 5.26\% of the respondents answered strongly disagree, $2.63 \%$ answered disagree and $39.47 \%$ answered neutral which meant they were not sure and $42.11 \%$ answered agree and $10.53 \%$ answered that they felt tensed when they knew there was oral assessment in English course outline. For item 3, 42.11\% of the respondents agreed that they their thoughts became confused and jumbled when they were asked to give a speech in English. From this result, it could be seen that the participants were not really confident to deliver their speech in English and it was probably due to lack of English vocabulary or fear of negative evaluation from friends which led to speaking anxiety.

For item 4, most of the participants answered agreed with the percentage of 65.79 and 5. $26 \%$ answered strongly agreed that they got anxious thinking about their upcoming English presentation. This showed that the participants had high level of speaking anxiety. Apart from that, for item $5,52.6 \%$ of the participants answered disagree, which showed that majority of the participants had fear of giving speech in English. For item 6, 52.63\% of the participants disagreed that they felt relaxed while doing oral presentation in English. For the item 7, 26.32\% of the participants answered disagree and $31.58 \%$ answered neutral that they found it hard to concentrate on the following parts of their speech if they made mistake while giving speech in English. For the item 8, 44.74\% of the participants agreed that they had difficulty to pronounce some English words during oral presentation. From the result of this item, it could be said that some of the students had problem with pronunciation while doing oral presentation. For item 9, majority or $44.74 \%$ of the participants answered agree, that they felt less anxious when working in group. Meanwhile, for item 10,42.11\% of the participants agreed that they felt less anxious if their teacher asked them to talk about something that they knew.

As a conclusion from this data analysis, it showed that majority of the participants had high level of speaking anxiety especially if they were asked to do oral assessment. The students were also not in favor of having the speaking class because they felt that this made them vulnerable and creating insecured feeling if they could not speak well in front of their friends. As a result, this put down their motivation in learning the language.

Table 1. Percentage of participants' responses on perceptions towards oral activities and their speaking anxiety levels

\begin{tabular}{|c|c|c|c|c|c|c|}
\hline Item & Question & SD & D & $\mathbf{N}$ & $\mathbf{A}$ & SA \\
\hline 1. & $\begin{array}{l}\text { While preparing for giving a speech in English, I } \\
\text { feel tensed and nervous. }\end{array}$ & 2.63 & 7.89 & 15.79 & 60.53 & 13.16 \\
\hline 2. & $\begin{array}{l}\text { I feel tense when I see the words 'speech' or } \\
\text { 'presentation' in my English course outline. }\end{array}$ & 5.26 & 2.63 & 39.47 & 42.11 & 10.53 \\
\hline 3. & $\begin{array}{l}\text { My thoughts become confused and jumbled when } \\
\mathrm{i} \text { am giving a speech in English. }\end{array}$ & 0 & 18.42 & 28.95 & 42.11 & 10.53 \\
\hline 4. & $\begin{array}{l}\text { I get anxious when I think about a speech being } \\
\text { presented in English coming up. }\end{array}$ & 5.26 & 5.26 & 18.42 & 65.79 & 5.26 \\
\hline 5. & I have no fear of giving a speech in English. & 2.63 & 52.63 & 28.95 & 7.89 & 7.89 \\
\hline 6. & $\begin{array}{l}\text { I feel relaxed while doing oral presentation in } \\
\text { English. }\end{array}$ & 0 & 52.63 & 26.32 & 15.79 & 5.26 \\
\hline 7. & $\begin{array}{l}\text { When I make a mistake while giving an English } \\
\text { speech, I find it is hard to concentrate on the } \\
\text { parts that follow. }\end{array}$ & 2.63 & 26.32 & 31.58 & 28.95 & 10.53 \\
\hline 8. & During my oral presentation, I experience some & 5.26 & 15.79 & 31.58 & 44.74 & 2.63 \\
\hline
\end{tabular}


difficulty in pronouncing English words.

9. When working in group, I feel less anxious to 0 speak in English.

10. I feel less anxious if my teacher asks me to talk 2.63 about something that I know.

$15.79 \quad 23.68 \quad 44.74$

15.79

$\begin{array}{llll}10.53 & 13.16 & 42.11 \quad 31.58\end{array}$

Meanwhile, questionnaire 2 was designed to know the perception of the participants on the usage of scaffolding speaking activities during speaking lessons to enhance their speaking skill and reduce speaking anxiety. Based on the table 2, it showed that $57.69 \%$ or 15 of the participants agreed that scaffolded impromptu speaking activities helped to boost their confidence in oral presentation. None of the participants responded strongly disagree or disagree for item 1. This showed that scaffolded speaking activities help them to improve their confidence level. For item 2, none of the respondents answered strongly disagree and disagree, $15.38 \%$ answered neutral which meant they were not sure and $65.38 \%$ answered agree and $19.23 \%$ answered that scaffolded impromptu speaking activities aid them to acquire new speaking skill. For item 3, $76.92 \%$ of the respondents agreed that scaffolded impromptu speaking activities helped them to stimulate ideas for oral presentation. From this result, it could be seen that impromptu speaking activities could encourage them to deliver their speech spontaneously.

For item 4, most of the participants answered agree with the percentage of $61.54 \%$ and $11.54 \%$ answered strongly agreed that they became more confident to speak in English. This showed that the participants have high level of confidence after experience scaffolded impromptu speaking activities. Apart from that, for item $5,3.85 \%$ or 1 of the participants answered strongly disagree, $42.31 \%$ answered neutral, $38.46 \%$ answered agree and $7.69 \%$ answered strongly agree that scaffolded impromptu speaking activities helped them to speak correctly regarding grammar. This result showed that by scaffolding speaking activities, it did not really mediate the participants in term of grammar. Same goes for item 6, 42.31\% answered neutral that scaffolded impromptu speaking activities could reduce their speaking anxiety. From this result, it revealed that, some of the participants still felt anxious when it came to speaking in English.

However, $38.46 \%$ or 10 of the participants agreed that scaffolded impromptu speaking activities could reduce their anxiety. For the item 7, majority of the participants agreed that they could share idea with their friends during impromptu speaking activities. For the item $8,34.62 \%$ of the participants strongly agreed and 46.15\% agreed that scaffolded impromptu speaking activities helped them to convey idea spontaneously. For item 9, majority or $50 \%$ of the participants answered neutral which means that they were not sure if they felt nervous when their English teacher asked them to do impromptu speaking activity. This showed that, they still felt anxious perhaps because they were not ready to talk in English or they were asked to talk about topics that they did not know. Meanwhile, for item 10,57.69\% of the participants agreed and $23.08 \%$ answered strongly agree that scaffolded impromptu speaking activities helped them to be a better English speaker. This revealed that scaffolded impromptu speaking activities improved their speaking skills.

As a conclusion from this data analysis, it showed that majority of the participants stated that scaffolded impromptu speaking activities could facilitate them to become a better English speaker and helped them to improve their speaking skills. 
Table 2. Percentage of participants' responses on the effectiveness of scaffolding impromptu speaking activities

\begin{tabular}{|c|c|c|c|c|c|c|}
\hline Item & Questions & SD & D & $\mathbf{N}$ & A & SA \\
\hline 1. & $\begin{array}{l}\text { Do you think scaffolded impromptu speaking } \\
\text { activities help to boost your confidence in oral } \\
\text { presentation? }\end{array}$ & 0 & 0 & 7.69 & 57.59 & 34.62 \\
\hline 2. & $\begin{array}{l}\text { Scaffolded impromptu speaking activities help } \\
\text { me to acquire new speaking skill. }\end{array}$ & 0 & 0 & 15.38 & 65.38 & 19.23 \\
\hline 3. & $\begin{array}{l}\text { Scaffolded impromptu speaking activities help } \\
\text { me to stimulate ideas for oral presentation. }\end{array}$ & 0 & 0 & 15.38 & 76.92 & 7.69 \\
\hline 4. & $\begin{array}{l}\text { Scaffolded impromptu speaking activities help } \\
\text { me to speak in English confidently. }\end{array}$ & 0 & 3.85 & 23.08 & 61.54 & 11.54 \\
\hline 5. & $\begin{array}{l}\text { Scaffolded impromptu speaking activities help } \\
\text { me to speak correctly regarding grammar. }\end{array}$ & 3.85 & 7.69 & 42.31 & 38.46 & 7.69 \\
\hline 6. & $\begin{array}{l}\text { I think impromptu speaking activities can } \\
\text { reduce my speaking anxiety. }\end{array}$ & 3.85 & 7.69 & 42.31 & 38.46 & 7.69 \\
\hline 7. & $\begin{array}{l}\text { I can share my idea with my friends during } \\
\text { impromptu speaking activities. }\end{array}$ & 0 & 3.85 & 15.38 & 57.69 & 23.08 \\
\hline 8. & $\begin{array}{l}\text { Scaffolded impromptu speaking activities help } \\
\text { to convey my idea spontaneously. }\end{array}$ & 0 & 0 & 19.23 & 46.15 & 34.62 \\
\hline 9. & $\begin{array}{l}\text { I feel nervous when my English teacher asks us } \\
\text { to do impromptu speaking activity. }\end{array}$ & 0 & 11.54 & 50 & 19.23 & 19.23 \\
\hline 10. & $\begin{array}{l}\text { Scaffolded impromptu speaking activities help } \\
\text { me to be a better English speaker. }\end{array}$ & 0 & 3.85 & 15.38 & 57.69 & 23.08 \\
\hline
\end{tabular}

\section{Qualitative data analysis result}

This section includes analysis of the focus group interviews conducted with the sub-sample of five interviewees. These analyses were used to answer the following research question: How do the students feel about the WhatsApp experience? The analysis of the students' feelings about the scaffolding speaking activities experience indicated that most of them liked the idea scaffolding speaking activities during speaking lessons and they felt that it contributed to their language performance especially in enhancing their oral performance and mediate them to reduce their speaking anxiety. The answers had been categorized according to themes as below:

a) Scaffolding impromptu speaking activities help to gain confidence in speaking

b) Advantages of Scaffolding Impromptu Speaking Activities

c) Enhance Speaking Skill

Some of the participants stated that they felt more confident to talk in English after they experienced all the interesting scaffolding speaking activities. Examples of the answers are:

i) In my opinion, the activity has helped me to build my confidence because the activities are fun and engaging. In fact, it is less formal and it allows your participation without any limit. I also can be myself without worrying about any constraints from the lecturer.

ii) Frankly speaking, I was shy in the first place yet after undergone the activities, I feel more prepared and comfortable in speaking in front of the public. I also feel that I have overcome the fear whereby I can control my anxiety when presenting. 
Next, participants were asked to indicate the advantages that they obtained from the experience during speaking lessons. The students gave different answers to this question. Three students reported that it created an opportunity for them to improve their fluency and pronunciation. Furthermore, they felt their speaking anxiety was reducing and mediate them in enhancing their speaking skill. Another student reported they felt more motivated to speak in English as their friends gave positive evaluation and feedback when they talked in English. Below were some examples of the participants' answers:

i) From the technical aspect, I am able to improve my fluency. This is because I bad problems in delivering the contents because I am too cautious with what am I saying as I was afraid that it is not clear enough. However, after weeks of training, I found that one of the activities has helped me a lot especially when it comes to public speaking session.

ii) I like all the speaking activities especially the mini project which we were asked to video recorded ourselves. It makes me become more motivated to improve my speaking skill.

iii) It gives me the opportunity to be myself when interacting with my friends. I always prefer to have my friends around me when doing this kind of activity because I feel more secure and motivated. Having supported by friends is important to me because it helps in boosting my confidence since I have supportive friends who will not laugh at me if I have mispronounced the words.

Finally, students indicated if they are eager to continue practicing scaffolded impromptu speaking activities for improving their speaking skills as a part of classroom activity for the future. However, other students reported that they could talk in English more confident and agreed to continue practicing scaffolded impromptu speaking activities during speaking lessons. Examples of the answers were as below:

i) It does help and I feel that I am ready to deliver my presentation. Now I feel that my friends will not laugh at me anymore because I am capable of pronouncing the words correctly as well as able to speak. clearly without any hesitations.

ii) The activities have helped me a lot because it allows personalisation whereby I can say anything I want according to my likings because there are activities which focus on the personal aspect of the learners.

Regarding the first research question of this study, levels of English anxiety among the students were high. Majority of the students stated that they felt anxious when they had to talk or give a speech in English. In the real language use situation, it is normal for second language learners to feel some anxiety. As stated by Khairi and Nurul Lina (2010), moderate feelings of anxiety in second language learning might help students to create the desire to learn, to motivate and to get the students realize that they should work harder to acquire the target language.

Teachers have to understand individual learner's strengths and weaknesses, and then to provide him or her with the necessary assistance through instruction so that he or she may meet the challenge independently. The problem of learners' speaking anxiety is one of the greatest obstacles teachers have to overcome in language classrooms. Scaffolding, as an instructional strategy, is a significant tool to contribute to the learning process because it provides opportunities for students to solve their learning problems.

The findings demonstrated that scaffolding provided students with the right balance of independence and support they needed to improve their English speaking performance. Scaffolding strategies makes it possible for the students to show improvements in their willingness to speak and participate in different tasks and activities in their English language classroom. 


\section{Conclusion and Recommendations/Implications}

In conclusion, this study gives evidences that scaffolding impromptu speaking activities contribute to the improvement of oral presentation skill. The results of the study also showed that the students experienced significantly less anxiety after they had been experienced of various interesting and fun speaking activities. Therefore, by creating a friendly, informal and learningsupportive environments for language learning by teachers' friendly, helpful and cooperative behaviour, it makes students feel comfortable when speaking in the class. This research is a very small research conducted in a very limited time. There are many variables which occurred but simply ignored by the researcher due to so many unavoidable constraints. For further research, the researcher would like to recommend a few important recommendations to other researchers who may be interested in doing the same research in the future.

First, one limitation of this study relates to time of doing this study. Maybe, dedicating more time and class sessions could lead to better results than it was in this study. The results of this research can make other researchers motivated to go through other dimensions of speaking through scaffolding to meet the needs of the learners. Secondly, this research was conducted a very small population of one class only. To obtain a more comprehensive result the research should be conducted to all the undergraduate students taking English courses. Thirdly, due to the time constraint, the researcher designed the questionnaire without piloting it. Therefore, for future research, in order to get valid and reliable data, questionnaire should be piloted before distribute to the participants. Other than that, for future research, questionnaire should be distributed with the students' present.

Finally, this study did not examine the link between anxiety and students with different ESL proficiency levels and furthermore, teacher perspectives are not within the scope of this study. Further research should include participants with varying ESL proficiency levels and language teaching professionals.

\section{References}

Campbell, C. M., \& Ortiz, J. A. (1991). Helping students overcome foreign language anxiety: A foreign language anxiety workshop. In E. K. Horwitz\& D. J. Young (Eds.), Language Anxiety: From theory and research to classroom implications (pp. 3-13). Englewood Cliffs, NJ: Prentice Hall.

Daly, J. A. (1991). Understanding communication apprehension: An introduction for language educators. In E. K. Horwitz\& D. J. Young (Eds.), Language Anxiety: From theory and research to classroom implications (pp. 3-13). Englewood Cliffs, NJ: Prentice Hall.

Ellis, R. (1996). The study of second language acquisition. Oxford, UK: Oxford University Press.

Hilleson, M. (1996). I want to talk with them but I don't want them to hear: an introspective study of second language anxiety in an English - medium school. In Bailey, K. , \& D. Nunan (Eds.) Voices from language classroom (pp. 248-276). Cambridge: Cambridge University Press.

Horwitz, E. K. Horwitz \& Cope, (1986). Preliminary evidence for the reliability and validity of a foreign language anxiety scale. TESOL Quarterly, 20(3), 559-562.

Horwitz, E. K. , Horwitz, M. B. , \& Cope, J. A. (1991). Foreign language classroom anxiety. In Horwitz, E. K. \& Young, D. J. (Eds.) Language Anxiety (pp. 27-39). Englewood Cliffs, NJ: Prentice Hall.

Kaya, M. (1995). The relationship of motivation, anxiety, self-confidence, and extroversion/introversion to students' active class participation in an EFL classroom in Turkey. (Undergraduate Thesis). Bilkent University, Turkey. 


\section{Edukasi}

Koba, N. , Ogava, N. , \& Wilkinson. D. (2000). Using the community language learning approach to cope with language Anxiety, The Internet TESL Journal, 6. Retrieved from http://www.aitech.ac.jp/ ;teslj/.

Khairi I. A. \& Nurul Lina A. R. (2010). A study on second language speaking anxiety among UTM students. $\quad$ Retrieved from http://eprints.utm.my/10275/2/Nurul_Lina_Bt_Abdul_Rahman.pdf.

MacIntyre, P. D. , \& Gardner, R. C. \& Moorcroft, R. (1987). The Role of Anxiety in Second Language Performance of Language Dropouts. Research Bulletin, 657. 3-26.

MacIntyre, P. D., \& Gardner, R. C. (1991). Language anxiety: Its relationship to other Anxieties and processing in native and second languages. Language Learning, 41, 513-534.

Price, M. L. (1991). The subjective experience of foreign language anxiety: Interviews with highly anxious students (pp. 101-107). In Horwitz, E. K. \& Young, D. J. (Eds.) Language Anxiety: from theory and research to classroom implications. Englewood Cliffs, NJ: Prentice Hall.

Suleimenova, Z. 2013. Speaking Anxiety in A Foreign Language Classroom in Kazakhstan. Retrieved from Https://Ac.Els-Cdn.Com/S1877042813035763/1S2.0S1877042813035763Main.Pdf?

Tallon, M. (2009). Foreign Language Anxiety and Heritage Students of Spanish: A Quantitative Study. Foreign Language Annals, 42(1), 112-137.

Tsui, A. B. M. (1996). Reticence and anxiety in second language learning. In Bailey, K. , \& Numan, D. (Eds.) Voices from language classroom. (pp. 145-168). Cambridge: Cambridge University Press.

Young, D. J. (1991). The relationship between anxiety and foreign language oral proficiency ratings, (pp. 5763). In Horwitz, E. K \& Young, D. J. (Eds.) Language Anxiety: from theory and research to classroom implications. Englewood Cliffs, NJ: Prentice Hall 